\title{
Salinity and Avocado Production, A Review
}

\author{
Abera Jaleta Berkessa* \\ Department of Horticulture, Bedele College of Agriculture and Forestry, Mettu University.
}

*Corresponding Author: Abera Jaleta Berkessa, Department of Horticulture, Bedele College of Agriculture and Forestry, Mettu University. Ethiopia.

\begin{abstract}
A rapidly increasing world population and the fast approaching geographical limitations of the world agriculture system have led to expansion of agricultural activities to marginal saline lands which may not suitable for crop production. So aim of the current review is to review and identify research gaps regarding the effect of salinity on photosynthesis and growth performance of avocado. Soil salinization is a serious threat to crop productivity and predicted to increase in the face of global climate change. It is one of the major abiotic constraints on agriculture worldwide, and the situation has worsened over the last 20 years due to the increase in irrigation requirements in arid and semi-arid regions. It is also one of the major factors reducing plant growth and productivity. It also cause decreases in photosynthesis. It is also one of the major factors limiting avocado production and productivity, because avocado is known to be the most saltsensitive cultivated fruit tree. Even low levels of salt inhibit the vegetative growth of the avocado shoot. In avocado production salinity stress induces a multitude of responses in plants including morphological, physiological, biochemical, and molecular changes. It reduces plant growth (both above, and belowground), stomatal conductance, photosynthetic rate, relative water content, leaf chlorophyll content, biomass accumulation and etc. It also induces interveinal leaf burn, scorch and dead tissues along the outside edges of leaves. Salinity can also seriously change the photosynthetic carbon metabolism, as well as photosynthetic efficiency. If the problem is not mitigated or any adaptation strategy is not followed the production and productivity of crop plant in general and avocado in particular will be affected at large.
\end{abstract}

Keywords: Avocado, salinity, growth, photosynthesis, stomatal conductance.

\section{INTRODUCTION}

Salinity refers to the occurrence of high concentrations of dissolved major inorganic ions in solution; including $\mathrm{Na}^{+}, \mathrm{Mg}^{2+}, \mathrm{Ca}^{2+}, \mathrm{K}^{+}, \mathrm{HCO}^{3-}, \mathrm{SO}^{2-}$ and $\mathrm{Cl}^{-}$(Mwai, 2001). The most common ions in the soil and at high concentrations are $\mathrm{Na}^{+}$and $\mathrm{Cl}^{-}$(Soussi et al., 1998). Saline soils are characterized by having an electrical conductivity higher than $4 \mathrm{dS} \mathrm{m} 1$ (where $4 \mathrm{dS} \mathrm{m} 1 \approx 40 \mathrm{mM} \mathrm{NaCl}$ ), which many crops are unable to tolerate (Qadir et al., 2000). It is formed under hot, arid conditions due to an accumulation of salts in the topsoil and form naturally or as a result of poorly managed irrigation (Mwai, 2001). Saline soils also occur where the supply of salts, for example from rock weathering capillary rise, rainfall or flooding, exceeds their removal; for example by leaching or flooding (Landon, 1991).

Salinity is one of the most significant environmental challenges limiting plant productivity, particularly in arid and semi-arid climates. It is one of the major abiotic constraints on agriculture worldwide, and the situation has worsened over the last 20 years due to the increase in irrigation requirements in arid and semi-arid regions. Salinization due to injudicious irrigation is recognized as being responsible for the loss of large tracts of agricultural land for cultivation (Mwai, 2001). Soil salinity affects about 7\% of the world's total land area (Musyimi, 2005) and 800 million hectares of arable lands worldwide (Munns and Tester, 2008).

Salinity/Salt stress is a global problem that limits crop production. It is also one of the major factors reducing plant growth and productivity (Musyimi, 2005). It also cause decreases in photosynthesis (Netondo et al., 2004a). Three major hazards associated with salinity are: - osmotic stress, ion toxicity and mineral deficiencies (Hasegawa et al., 2000; Netondo et al., 2004a). Soil salinity not only delays but also reduces flowering and yield of crop plants.

Avocado is known to be the most salt-sensitive cultivated fruit tree. Even low levels of salt inhibit the vegetative growth of the avocado shoot (Bernstein et al., 2001; Mickelbart and Arpaia, 2002). 
Chloride and sodium concentrations in irrigation water, which are considered tolerable for many crops, induce severe leaf damage in avocado. Salt-induced leaf damage is considered to reduce the photosynthetic leaf area and hence yield potential in avocado.

Different projection works have been done on futurity of salinity. The global projection show that salt-affected soils are increasing particularly in irrigated areas. In the last decades salt-affected areas have been reported to increase from 20\% (45 million hectares) to $33 \%$ (74.25 million hectares) (Metternich and Zinck, 2003; Kumar and Shrivastava, 2015). These figures suggest that at a global scale, every day an area of about 2000 ha of irrigated crop land is affected by varying levels of salinity (Qadir et al., 2014).

Therefore, it has been estimated that more than $50 \%$ of the arable land would be salinized by the year 2050 (Jamil et al., 2011). Due to seriousness of the problem and its future impacts on avocado production, there is a need to review the effect of salinity on avocado photosynthesis and growth. Therefore this review is intended with the following objectives;

- To review and identify research gaps regarding the effect of salinity on photosynthesis and growth performance of avocado

\section{Soil Salinity ANd A vocado Production}

\subsection{Effect of Soil Salinity on Photosynthesis}

Salinity is known to be out of the major problems affecting photosynthesis of crops plants which in turn, affect crop growth and yield. Different authors were being appreciating the impacts of salinity. Soussi et al., (1998) observed that salinity drastically affects photosynthesis.

Salinity affects photosynthesis both in the short and long term. In the short term, salinity can affect photosynthesis by stomatal limitations, leading to a decrease in carbon assimilation (Parida and Das, 2005). This effect can produce rapid growth cessation, even after just a few hours of salt exposure (Hernández and Almansa, 2002). In the long term, salt stress can also affect the photosynthetic process due to salt accumulation in young leaves (Munns and Tester, 2008) and decreases in chlorophyll and carotenoid concentrations even in halophyte plants (Parida and Das,2002; Duarte et al., 2013). The photosynthesis rate (PN) can drop due to stomatal closure (gs), and/or other nonstomatal limitations, like the disturbance of the photosynthetic electron chain and/or the inhibition of the Calvin Cycle enzymes, such as Rubisco, phosphoenol pyruvate carboxylase (PECP), ribulose-5phosphate kinase, glyceraldehyde-3-phosphate dehydrogenase or fructose-1,6-bisphosphatase (Chaves et al., 2009; Parida and Das, 2002). A drop in gs can prevent excess water loss by transpiration, whereas proper regulation of the photosynthetic process can minimize the generation of ROS in PS II and in the reducing side of the PSI (Asada, 1999).

Salinity reduces photosynthesis, stomatal conductance and water potential in leaves of citrus trees (Bañuls and PrimoMillo, 1992). Salinity can seriously change the photosynthetic carbon metabolism, leaf-chlorophyll content, as well as photosynthetic efficiency (Netondo, 1999; Sibole et al., 2003).

Reduction in photosynthesis is directly related to stomatal conductance, though non-stomatal factors are also associated with lower photosynthetic capacity in salt treated plants (Ashraf et al., 2002; Netondo et al., 2004a).

Schaffer and Whiley (2003) have indicated that stomatal conductance is a more reliable early indicator of stress in avocado than measurements of leaf water content, leaf water potential or growth variables.

The research output of Musyimi et al., (2007a) shows that total chlorophyll content was higher at control than at salt treated plants. Chlorophyll content decreased at higher salinities. Net photosynthetic rate of salinized plants was 63.6 to $93.3 \%$ of the control plants after 39 days. Salinity treatment had significant effect on $\mathrm{PN}(\mathrm{p} \leq 0.05)$ after 39 days of salt application. Transpiration rate (E) decreased in response to increasing salt concentration of the growth medium. From 15 to $60 \mathrm{mM}$ $\mathrm{NaCl}$, the decreases in $\mathrm{E}$ were 94.1, 93.9, 95.1 and $87.9 \%$ of control plants respectively after 39 days.

Another finding indicated that net photosynthesis is strongly affected by $\mathrm{NaCl}$ saline conditions and is directly related to reduction in stomatal conductivity as well as low intercellular $\mathrm{CO} 2$ levels. Rates of CO2 fixation decreased when levels of chloride in the leaves increased (Banuls and Primo-Millo, 1992). 


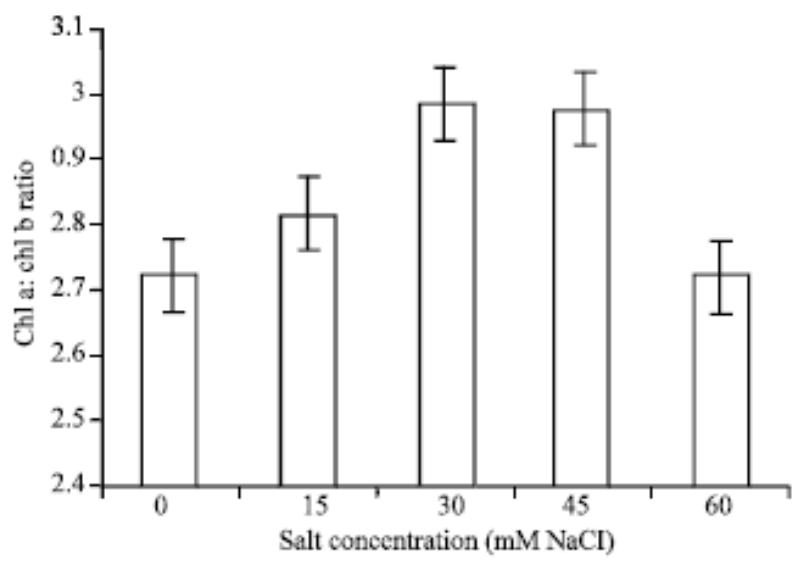

Fig3. The effect of saline water irrigation on Chal a: Chl b ratio of avocado seedling after 39 days. Each value is the mean of four replications $\pm S E$

Source: Musyimi et al., (2007a)

\subsection{Effect of Salinity on Growth of Avocado}

Salinity is one of the factors affecting growth and development of fruit in general and avocado in particular. Different scholars are confirming that salinity is adversely affecting plant growth and development (Lazof and Bernstein, 1997). It had a significant influence on the growth pattern of the avocado seedlings. Worldwide, the effects of salinity on plant growth and development are increasingly problematic (Musyimi et al., 2007a).

Excess soil salinity causes poor and spotty stands of crops, uneven and stunted growth and poor yields, the extent depending on the degree of salinity. It reduces plant growth through osmotic and toxic effects, and high sodium uptake ratio values cause sodicity, which increases soil resistance, reduces root growth, and reduces water movement through the root with a decrease in hydraulic conductivity (Rengasamy and Olsson, 1993).

Schachtman and Munns, (1992) concluded that the salts absorbed by plants do not control growth directly, but that they do influence turgor, photosynthesis and/or the activity of specific enzymes. Demonstrating the complexity of salts tress, this author developed a model showing a two-phase effect of salinity on plant growth. Growth is first reduced by a decrease in the soil water potential (osmotic phase) and, later, a specific effect appears as salt injury in leaves, which die because of a rapid increase in salt in the cell walls or cytoplasm when the vacuoles can no longer sequester in coming salts(ionic phase). Schachtman and Munns, (1992) also found that this salt accumulation in the old leaves accelerates their death and thus decreases the supply of carbohydrates and/or growth hormones to the meristematic regions, thereby inhibiting growth.

Decrease in photosynthesis could be an indirect consequence of impaired physiology of plants growing under salinity stress (Munns, 2002). Research by Mickelbart and Arpaia (2002) has indicated that sensitivity to salinity among avocado cultivars was reflected in different growth reductions and leaf necrosis.

Salt stress can lead to a considerable decrease in the fresh and dry weights of leaves, stems, tillers, fertile tillers and roots of susceptible (Dolo, 2018).

Musyimi et al., (2007a) observed that growth at high salinity resulted in large reductions in fresh and dry weight production of both shoot and root (Table 4). The reduction in shoot dry weight was attributed to lower leaf number and development of smaller leaves with increased salinity of the growth medium.

Bonomelli et al., (2018) observed that the dry weight of the aerial part (leaves and stems), roots and for the entire plant in the treatments without the stress (T0 and T0 $+2.25 \mathrm{SW}$ ) were always significantly higher than treatments with saline irrigation, regardless of the addition of SW. The decrement being, 50\% compared to control plants on average. In the case of the roots, mean values for TS and T0 were $150 \mathrm{~g}$ plant -1 versus $300 \mathrm{~g}$ plant -1 , for shoots it was $153 \mathrm{~g}$ plant -1 versus $273 \mathrm{~g}$ plant -1 , and leaves were $88 \mathrm{~g}$ plant -1 and $165 \mathrm{~g}$ plant -1 , respectively treatment. 
Another finding of Bonomelli et al., (2018) indicated that saline irrigation decreased, by $50 \%$, the fresh weight of all plant tissues compared to samples watered with distilled water, with T0 having a significantly different in final fresh weight total compared to TS. In addition to this Munns and Rawson, (1999), observed an inhibition of vegetative development of the shoots and roots as the primary response to salt stress, in which the roots and stems showed 50\% and 56\% less fresh weight in saline conditions compared to the control.

Table4. Analysis of growth parameters after 39 days of saline water irrigation

\begin{tabular}{lccc}
\hline Treatment $\mathrm{NaCl}(\mathrm{mM})$ & Root fresh weight $(\mathrm{g})$ & Root day weight $(\mathrm{g})$ & Shoot fresh weight $(\mathrm{g})$ \\
\hline 0 & $60.425 \mathrm{a}$ & $20.425 \mathrm{a}$ & $90.88 \mathrm{a}$ \\
15 & $33.500 \mathrm{~b}$ & $10.425 \mathrm{~b}$ & $84.00 \mathrm{a}$ \\
30 & $24.875 \mathrm{~b}$ & $6.450 \mathrm{~b}$ & $82.33 \mathrm{ab}$ \\
45 & $24.075 \mathrm{~b}$ & $5.850 \mathrm{~b}$ & $50.35 \mathrm{bc}$ \\
60 & $22.750 \mathrm{~b}$ & $4.900 \mathrm{~b}$ & $41.00 \mathrm{c}$ \\
LSD & 20.44 & 6.6741 & 30.092 \\
\hline
\end{tabular}

Source: Musyimi et al., (2007a)

Ahmed and Ahmed (1997) found reduction in all growth characters (height, number of leaves, leaf area and stem thickness) with increasing levels of salinity.

Bonomelli et al., (2018) found that salinity reduced shoot height in approximately $74 \%$ of the avocado plants, while the stem diameter was also reduced by $63 \%$ in the control plants. In Bernstein et al., (2001), study the plant height and the stem diameters in avocado were 78 and $86 \%$ of the control, respectively.

Analyzing the differences in growth of plants subjected to different treatments of the experiment at 30 days, Bonomelli et al., (2018) observed a decrease in plant height and leaf number in TS compared to T0 (17\% and 36\%, respectively). Furthermore, the height of the plants and the number of leaves of TS $+1.5 \mathrm{SW}$ differed from those in $\mathrm{T} 0$ by $12 \%$ and $8 \%$, respectively. TS $+2.25 \mathrm{SW}$ were determined to present a difference from $\mathrm{T} 0$ of $1 \%$ in height and $6 \%$ in the number of leaves.

Musyim et al., (2007a) observed that salinity significantly increased stem diameter in $15 \mathrm{mM}$ treatment, in the first few days after initiation of salt treatments. Generally, salt treated seedlings had significantly smaller stem diameter than control plants. Accordingly, stem diameter growth inhibition was $71.8 \%$ of control plants values at $60 \mathrm{mM} \mathrm{NaCl}$. Overall, salinity reduced the final numbers of leaves per plant, from 100 to $22.5 \%$ at $60 \mathrm{mM} \mathrm{NaCl}$ treatment and prolonged the duration of development of new leaves over the study period. Growth at high salinity resulted in large reductions in dry matter production of both shoot and root, i.e., 37.5 and $19.1 \%$, respectively at $60 \mathrm{mM} \mathrm{NaCl}$ (Table 5).

Table5. Effects of five levels of $\mathrm{NaCl}$ salinity on the growth and leaf water content (LWC) of avocado seedlings, after 8 weeks

\begin{tabular}{llcccr}
$\begin{array}{l}\text { Treatment } \\
\mathrm{NaCl}(\mathrm{mM})\end{array}$ & $\begin{array}{l}\text { Shoot height } \\
(\mathrm{cm})\end{array}$ & $\begin{array}{l}\text { Stem diameter } \\
(\mathrm{mm})\end{array}$ & $\begin{array}{l}\text { Leaf No. } \\
\text { per plant }\end{array}$ & $\begin{array}{l}\text { Shoot dry matter } \\
\text { content }\left(\mathrm{g} \mathrm{plant}^{-1}\right)\end{array}$ & $\begin{array}{r}\text { Root } \\
\text { conter }\end{array}$ \\
\hline 0 (control) & $109.9 \pm 2.1 \mathrm{a}$ & $13.1 \pm 0.7 \mathrm{a}$ & $112.6 \pm 2.1 \mathrm{a}$ & $27.5 \pm 0.8 \mathrm{a}$ & 19. \\
15 & $102.2 \pm 2.1 \mathrm{a}$ & $12.5 \pm 0.4 \mathrm{ab}$ & $98.5 \pm 1.6 \mathrm{~b}$ & $26.7 \pm 2.4 \mathrm{a}$ & 10. \\
30 & $99.6 \pm 1.3 \mathrm{a}$ & $11.5 \pm 0.2 \mathrm{~b}$ & $76.2 \pm 2.1 \mathrm{c}$ & $17.8 \pm 2.9 \mathrm{~b}$ & 8. \\
45 & $86.9 \pm 2.6 \mathrm{a}$ & $11.2 \pm 0.2 \mathrm{~b}$ & $64.3 \pm 1.3 \mathrm{~d}$ & $15.6 \pm 2.2 \mathrm{~b}$ & 5. \\
60 & $52.1 \pm 4.3 \mathrm{a}$ & $9.4 \pm 0.1 \mathrm{c}$ & $25.3 \pm 3.1 \mathrm{e}$ & $10.3 \pm 1.5 \mathrm{c}$ & 3. \\
\hline
\end{tabular}

(Each value is the mean of four plants \pm SE of the mean). Means followed by different letter(s) are significantly different at $\mathrm{p} \leq 0.05$.

Source: Musyimi et al., (2007a)

Interestingly, root to shoot ratio was reported to decrease under salt stress (Bar et al., 1997) suggesting that, contrary to most crop species, the avocado root system might be more sensitive to salt stress than its shoot. Substantial root growth inhibition might conceivably be an important component in the tree's response to the stress.

Research done by Chartzoulakis and Klapaki (2000) using solution containing 0, 10, 25, 50, 100 and $150 \mathrm{mM} / \mathrm{l}$ of $\mathrm{NaCl}$., indicate that at vegetative growth stage (6 weeks after planting), the plant height, the leaf area and the dry weight were significantly reduced at salinities higher than $25 \mathrm{mM} \mathrm{NaCl}$. The 
plant height decreased significantly with increasing salinity, the reduction being 20,31 and $44 \%$ of the control for 'Sonar' and 29, 40 and 49\% of the control for 'Lamuyo' at 50,100 and $150 \mathrm{Mm}$, respectively. Total leaf area reductions were greater than those of height: 39,56 and $70 \%$ of the control for 'Sonar' and 42, 66 and 82\% of the control for 'Lamuyo' at 50, 100 and $150 \mathrm{mM}$, while total dry weight reductions for those salinities were smaller.

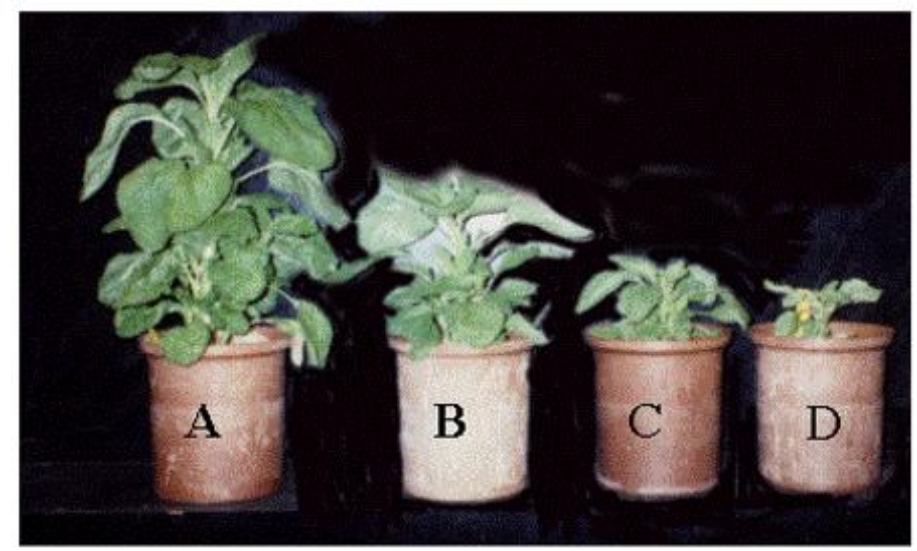

Fig12. Amaranthus tricolor plants salinized with (A) $0 \mathrm{mM}$, (B) $25 \mathrm{mM}$, (C) $50 \mathrm{mM}$ and (D) $100 \mathrm{mM} \mathrm{NaCl}$ solution.

Source: Omami (2005)

\section{SUMMARY AND CONCLUSION}

A rapidly increasing world population and the fast approaching geographical limitations of the world agriculture system have led to expansion of agricultural activities to marginal saline lands which may not suitable for crop production. Soil salinization is a serious threat to crop productivity and predicted to increase in the face of global climate change. It is one of the most important abiotic stresses, limiting crop production mainly in arid and semi-arid regions, where soil salt content is naturally high and precipitation can be insufficient for leaching. It is also one of the major factors limiting avocado production and productivity.

Salinity stress induces a multitude of responses in plants including morphological, physiological, biochemical, and molecular changes.

Salinity reduces plant growth (both above, and belowground), stomatal conductance, photosynthetic rate, relative water content, leaf chlorophyll content, biomass accumulation and etc. It also induces interveinal leaf burn, scorch and dead tissues along the outside edges of leaves. Salinity can also seriously change the photosynthetic carbon metabolism, as well as photosynthetic efficiency.

Salinity is a major ecological problem which needs to be addressed. If the problem is not mitigated or any adaptation strategy is not followed the production and productivity of crop plant in general and avocado in particular will be affected at large.

\section{THE WAY FORWARD}

- Salinity tolerating avocado varieties is scarce. So, future research should focus on market assisted selection of genotypes for salinity tolerance.

- The application of genetic engineering in future research is also paramount important.

- Site specific recommendation is very important in alleviating the salinity problem.

- Further research is needed to dig out more management options.

- In future research it is good if different modeling is done for projection of the impacts of salinity.

\section{REFERENCES}

[1] Ahmed. A.M. and Ahmed, EE (1997). Ann. Agric. Sci. 35: 901-908.

[2] Ashraf, M., F. Karim and E. Rasul, (2002). Interactive effects of gibberellic acid (GA3) and salt stress on growth, ion accumulation and photosynthetic capacity of two-spring wheat (Triticum aestivum L.) cultivars differing in salt tolerance. Plant Growth Reg., 36: 49-59.CrossRef. 
[3] Asada K. (1999). The water-water cycle in chloroplasts: Scavenging of active oxygen and dissipation of excess photons. Ann. Rev. Plant Physiol. Plant Mol. Biol., 50: 601-639. [CrossRef] [PubMed].

[4] Bar, Y., A. Apelbaum, U. Kafkafi, and R. Goren (1997). Relationships between chloride and nitrate and its effect on growth and mineral composition of avocado and citrus plants. J. Plant Nutr. 20(6):715-731.

[5] Bañuls J and Primo-Millo E. (1992). Effects of Chloride and Sodium on gas exchange parameters and water relations of Citrus plants. Physiol.plant. 86: 115-123.

[6] Bernstein N., Meiri, A. and Zilbersaine M. (2001). Salt-stress effects on avocado rootstock growth. I. Establishing criteria for determination of shoot growth sensitivity to the stress. Plant Soil , 233, 1-11. [Google Scholar] [CrossRef].

[7] Bonomelli Claudia, Celis Valentina , Lombardi Gian and Mártiz Johanna (2018). Salt Stress Effects on Avocado (Persea americana Mill.) Plants with and without Seaweed Extract (AscophyllumnodosumApplication.Agronomy; 8(5),64; https://doi.org/10.3390/agronomy8050064.

[8] Chartzoulakis K.and Klapaki G. (2000). Response of two greenhouse pepper hybrids to $\mathrm{NaCl}$ salinity during different growth stages. Scientia Horticulturae : 86, $247 \pm 260$.

[9] Chaves, M.M.; Flexas, J.; Pinheiro, C. (2009). Photosynthesis under drought and salt stress: Regulation mechanisms from whole plant to cell. Ann. Bot. 103, 551-560. [CrossRef] [PubMed].

[10] Dolo J. S. (2018). Effects of Salinity on Growth and Yield of Rice (Oryza Sativa L.) and Development of Tolerant Genotypes in Kilosa District, Tanzania. A Thesis Submitted Sokoine University of Agriculture. Morogoro, Tanzania.

[11] Duarte,B.;Santos,D.;Marques,J.C and Caçador,I.Ecophysiological adaptations of two halophytes to salt stress: Photosynthesis, PS II photochemistry and anti-oxidant feedback-Implications for resilience in climate change (2013). Plant Physiol. Biochem., 67, 178-188. [CrossRef] [PubMed].

[12] Hasegawa, P.M., R.A. Bressan, J.K. Zhu and H.J. Bohnert, (2000). Plant cellular and molecular responses to high salinity. Annu. Rev. Plant Physiol. Plant Mol. Biol., 51: 463-499.Cross Ref.

[13] Hernández, J.A.; Almansa, M.S. Short-term effects of salt stress on antioxidant systems and leaf water relations of pea plants. Physiol. Plant. 2002, 115, 251-257. [CrossRef] [PubMed].

[14] Jamil, A., Riaz, S., Ashraf, M. and Foolad, M.R. (2011). Gene expression profiling of plants under salt stress. Critical Review of Plant Science, 30(5): 435-458.

[15] Kumar, R. and Shrivastava, P. (2015). Soil salinity: A serious environmental issue and plant growth promoting bacteria as one of the tools for its alleviation, Saudi Journal of Biological Sciences, 22: 123-131.

[16] Landon JR. (1991). Booker Tropical soil manual. A handbook for soil survey and agricultural land evaluation in the tropics and subtropics. Paperback edition. Booker Tate Limited. England.

[17] Lazof, D. and N. Bernstein, (1997). The NaCl-induced inhibition of shoot growth: The case for disturbed nutrition with special consideration of calcium nutrition. Adv. Bot. Res., 29: 115-189.

[18] Metternicht, G.I. and Zinck, J.A. (2003). Remote sensing of soil salinity: Potentials and constraints. Remote Sensing of Environment, 85(1): 1-20, ISSN 0034-4257.

[19] Mickelbart, M.V. and M.L. Arpaia, (2002). Rootstock influences changes in ion concentration, growth and photosynthesis of Hass avocado trees in response to salinity. J. Am. Soc. Hortic. Sci., 127: 649-655.

[20] Munns R.(2002). Comparative physiology of salt and water stress. Plant. Cell and Environ. 25: 239-250.

[21] Munns, R and Tester, M. (2008). Mechanisms of salinity tolerance. Ann. Rev. Plant Biol. 59, 651-681. [CrossRef] [PubMed].

[22] Musyimi, D.M., (2005). Evaluation of young avocado plants (Persea americana Mill.) for tolerance to soil salinity by physiological parameters. M.Sc. Thesis. Maseno University, Kisumu, Kenya.

[23] Musyimi D.M., N etondo G.W. and Ouma G., (2007a). Effects of Salinity on Growth and Photosynthesis of Avocado Seedlings. International Journal of Botany, 3: 78-84. 10.3923/ijb.2007.78.84. https://scialert.net/abstract/?doi=ijb.2007.78.84.

[24] Munns, R. and Rawson, H. (1999). Effect of salinity on salt accumulation and reproductive development in the apical meristem of wheat and barley. Aust. J. Plant Physiol. , 26, 459-464. [Google Scholar] [CrossRef

[25] Mwai GN. (2001). Growth responses of spider plant (Cleome gynadra L.) to salinity. M.Sc thesis, Maseno University. Kenya.

[26] Netondo GW, Onyango JC, Beck E. (2004a). Sorghum and salinity: Gas exchange and chlorophyll fluorescence of sorghum under salt stress. Crop Sci. 44: 806-811.

[27] Netondo GW. (1999). The use of physiological parameters in screening for salt tolerance in Sorghum (Sorghum bicolor L. Moench) varieties grown in Kenya; Ph.D. thesis, Maseno University, Kenya. 
[28] Parida, A.; Das, A.B.; Das, P. (2002). NaCl stress causes changes in photosynthetic pigments, proteins, and other metabolic components in the leaves of a true mangrove, Bruguiera parviflora, in hydroponic cultures. J. Plant Biol., 45, 28-36. [CrossRef].

[29] Qadir M, Ghafoor A, Murtaza G (2000). Amelioration strategies for saline soils: a review. Land Degradation \& Development, 11, 501-521.

[30] Qadir, M., Quillérou, E., Nangia, V., Murtaza, G., Singh, M. Thomas, R.J., Drechsel P., and Noble, A.D. (2014). Economics of salt-induced land degradation and restoration. Natural Resources Forum, 38: 282-295.

[31] Rengasamy, P.; Olsson, K.A. (1993). Irrigation and sodicity. Aust. J. Soil Res., 31, 821-837. [CrossRef].

[32] Schachtman, D.P. and Munns, R., 1992. Sodium accumulation in leaves of Triticum species that differ in salt tolerance. Functional Plant Biology, 19(3), pp.331-340.

[33] Schaffer, B. and A.W. Whiley, (2003). Environmental regulation of photosynthesis in avocado trees-A mini-review. Proceedings of the 5th World Avocado Congress (Actas V congreso Mundial del Aguacate), October 19-24, 2003, Spain, pp: 335-342.

[34] Sibole JV, Cabot C, Poschenrieder C, Barcelo J. (2003). Efficient leaf ion partitioning; an overriding condition for abscisic acid-controlled stomatal and leaf growth responses to $\mathrm{NaCl}$ salinization in two legumes. J. Exp. Bot. 54: (390), 2111-2119.

[35] Soussi, M., A. Ocana and C. Lluch, (1998). Effect of salt stress on growth, photosynthesis and nitrogen fixation in chickpea (Cicer arietinum L.). J. Exp. Bot., 49: 1329-1337.

[36] SPORE (1995). Water, the Limiting Resource. CTA, 57: 1-4.

Citation: Abera Jaleta Berkessa., " Salinity and Avocado Production, A Review", International Journal of Forestry and Horticulture (IJFH), vol. 6, no. 1, pp. 32-38, 2020. Available: DOI: http://dx.doi.org/ 10.20431/ 2454-9428.0601004

Copyright: () 2020 Authors. This is an open-access article distributed under the terms of the Creative Commons Attribution License, which permits unrestricted use, distribution, and reproduction in any medium, provided the original author and source are credited. 